\title{
Life Spectacles: Media, Business Synergy and Affective Work in Neoliberal China
}

\author{
Hai Ren, University of Arizona
}

\begin{abstract}
[A] substantial reconfiguration of social relations within and around the Chinese media ... involves two processes - the (re)enfranchisement of the media elite as the cultural component of the ruling bloc and, through their work, the rearticulation of ruling ideas, the reformation of social consciousnesses, and the reconstitution of the population's subjectivities as part of the reconfiguration of structural power relations in society at large. (Zhao 2008:82)
\end{abstract}

This paper offers a close examination of a significant Chinese media event in July 2000 in order to explore how synergy operates as a mechanism that transcends the boundaries among seemingly different modes of cultural production. Here, synergy temporarily formed a circuit of connections among different actors: a television company, Beijing dianshitai shenghuo pindao (Beijing Television Station Life Channel, BTSLC); a theme park company, the Chinese Ethnic Culture Park; and two local governments, one in Yunnan, another in Qinghai. Moreover, synergy operated as a technique of capital accumulation that was based on the affective work of ethnic minority workers, mostly migrants from poor rural regions in western and southwestern China. Overall, business synergy between two media forms - television and the built environment - and affective work contributed to the project of socially re-engineering China as a 'middle class' society. ${ }^{1}$

\footnotetext{
${ }^{1}$ I agree with Jing Wang's argument that marketing is a 'missing link in studies of the relationship between popular culture and consumer culture' (2005: 533). Her study focuses on the marketing of a particular lifestyle (bobo) as a way of life. In my case here, synergy is a marketing tool, but it focuses on the process and practice of converting products and services into capital. For this reason, synergy concretely links together the economic and the social.
}

PORTAL Journal of Multidisciplinary International Studies, vol. 6, no. 2, July 2009.

Post-Mao, Post-Bourdieu: Class and Taste in Contemporary China, Special Issue, guest edited by Yi

Zheng and Stephanie Hemelryk Donald.

ISSN: 1449-2490; http://epress.lib.uts.edu.au/ojs/index.php/portal

PORTAL is published under the auspices of UTSePress, Sydney, Australia. 
In the evening of July 15, 2000, a group of reporters from the Beijing Television Station Life Channel arrived at the Chinese Ethnic Culture Park to report how Beijing residents spent their leisure time in the summer. They videotaped the welcoming ceremony and the performance of ethnic songs and dances, as well as visitors' activities. They asked ethnic minority workers to explain 'ethnic culture,' tasted 'ethnic foods,' and participated in the water splashing festival. Meanwhile, the ethnic minority workers (representing the Jingpo, Zang, Dai, Miao, Yi, and De'Ang) at the park staged a spectacular performance. They put on make-up, wore their most elaborate costumes, and sang and danced with enthusiasm. They did not only explain the meanings of their clothing; they also repeatedly introduced their 'beautiful homes' to 'audience friends' and invited them to visit.

Despite its mundane nature, this media event pointed to the way in which the ethnicwhether as a specific meaning or as a marker of the cultural other-is circulated across various terrains of the cultural industry or 'cultural enterprise' (wenhua chanye) in neoliberal China. From the viewpoint of television journalists, the ethnic festival seemed to provide an exciting opportunity for Beijing residents to spend their summer; their participation in the ethnic festival is a 'non-political' activity, a matter of leisure rather than of an official politics. From the perspective of the theme park, however, the ethnic festival is not just a mater of leisure consumption. It is also a celebration of China's ethnic diversity, and an expression of Chinese multiculturalism. The media event was thus treated as an opportunity for promoting ethnic tourism and modernizing development in poor minority regions. The two different treatments of ethnic performance reflect how spectacles of everyday life - in this case, of mundane leisure, and of the cultural representation of 'ethnic culture' - contribute to the project of socially re-engineering China as a Chinese 'middle class' society.

Since the late 1970s, China's 'reform and opening' (gaige kaifang) has extracted individuals from the social institutions developed under socialism and re-embedded them within a new sociopolitical system. The ways in which individuals become socialized as Chinese citizens have changed. Not only are the institutional structures of socialist China disappearing but forms of practical knowledge, common sense, and guiding norms associated with socialism are no longer legitimate tools of empowerment. Increasingly, Chinese citizens have to rely on themselves. For example, the socialist 
work unit (danwei) was not only a workplace but an entire welfare system (Wang 2003; Bray 2005). It provided employment, housing, child-care, health care, and education. However, market-based reforms, especially of the state-owned enterprises that employed the majority of workers, have resulted in the withering away of these work units and the social networks formed through them. ${ }^{2}$ They have effectively reduced the state's welfare function. Some individuals have taken advantage of new opportunities to become active participants in the market. Meanwhile, millions of laid-off workers face new challenges in making a living. Some have been retrained to take temporary and part-time employment, including domestic helpers and service sector workers (Yan 2008); others have become permanently unemployed because they are unable to compete with the growing number of young migrant laborers from rural areas (Pun 2005) or with new college graduates with knowledge of international business and work practices (Ross 2006: 18).

The embrace of a market economy, with all its attendant risks, has forced the development of new governmental and social policies to stabilize China's social structure through the conceptual category of the 'middle class' (Ren forthcoming b). Under this historical condition, Chinese media play an important role in the articulation of ruling ideas, the reformation of social consciousnesses, and the reconstitution of subjectivities (Zhao 2008: 82). The two representations of the ethnic festival on July 15, 2000, which I will discuss in detail based on my ethnographic observations and interviews, are different interpretations of everyday life, but they work together to convey core values of neoliberalism such as market rationality and entrepreneurism. Both rely on communication as the means of production for manufacturing cultural commodities and their associated feelings. Moreover, the interpretations of life's meanings and values are part of the governmental apparatuses that aim to manage, govern, control, and orient the behaviours, gestures, and thoughts of Chinese citizens in order to transform them into 'middle class' subjects, responsible for the existing and potential risks of Chinese society. In this essay, I use the term 'life spectacle' to characterize these media effects.

\footnotetext{
${ }^{2}$ This systematic change means neither that the exiting state-owned enterprises no longer perform welfare functions, nor that their employees are not well paid compared with those of private companies.
} 


\section{Life spectacle}

The concept of 'spectacle' is commonly associated with Guy Debord's work. He refers to 'the spectacle' as a system dominated by a mode of social life in which 'all that was directly lived has become mere representation' (1995: 12, thesis 1). In this society of the spectacle, 'the spectacle is not a collection of images; rather, it is a social relationship between people that is mediated by images' (1995: 12, thesis 4). Like Marx, Debord points out the spectacle's alienating effects by arguing that commodity relations displace human relations. My concept of life spectacle builds on Debord's work to describe three ways in which spectacles become governmental apparatuses in the regulation of life.

First, life spectacle refers to a mediated cultural process that affects the way in which we perceive, act upon, and function in everyday life. In the context of China, life spectacles are inseparable from the transformation of 'culture institutions' (wenhua jigou), which used to be solely owned and controlled by the Chinese government, into 'culture enterprises.' Regardless of their ownerships, these culture institutions operate through the logic of the market. The Beijing Television Station Life Channel, for example, is a joint venture between Beijing Television Station, owned and administered by the Beijing Municipal Government, and Beijing Yinhan Cultural Communications Ltd., a private television production company. The joint venture, resulting in one of the first private television production companies in China, exemplifies an important trend in China's television industry: 'the separation of production from broadcast' (zhibo fenli). By comparison, the Chinese Ethnic Culture Park, one of the largest ethnic theme parks in the country, is a leisure and tourist company established primarily through Taiwanese investment. Despite different types of business operations, both companies involve cultural production and consumption, whether of news, entertainment, or ethnic displays and performances.

Second, I use life spectacle to emphasize the rising importance of communication in contemporary capitalism. In the late 1940s, the scholars of the Frankfurt School such as Adorno and Horkheimer used 'the culture industry' to refer not only to the industrial production, distribution, and exhibition of cultural objects such as movies, music, television shows, advertisements, magazines, and novels; but also to the effects of standardization and mechanization in media culture (Horkheimer \& Adorno 2001: 74- 
93; Marcuse 1991). In the context of globalization since the 1970s, in which China plays a critical part, the post-Fordist mode of capitalism ${ }^{3}$ demands communicative and creative improvisation to achieve productivity and profitability (Virno 2004: 58-61). Consequently, the communication industry has developed rapidly. Thus, life spectacle as a staged public communication has more than one meaning. First, it is a specific product of a cultural industry. Moreover, in the post-Fordist context, it is also an essential ingredient of productive cooperation in general, something that goes beyond its own industrial domain to play the role of the 'industry of the means of production' (Virno 2004: 61). The two companies discussed in this paper represent two different industries, but they do not operate in isolation. Rather, they are connected through media convergence, business synergy, and affective labor, all of which deploy communication as the means of production.

In addition to media culture and communicative capitalism, the third meaning of life spectacle is tied to the governance of society. 'If the spectacle- understood in the limited sense of those 'mass media' that are its most stultifying superficial manifestation - seems at times to be invading society in the shape of a mere apparatus,' Debord argues, 'it should be remembered that this apparatus has nothing neutral about it, and that it answers precisely to the needs of ... the administration of society' (1995: 19, thesis 24). I would add that the spectacle becomes a governmental apparatus when it begins to communicate 'life' as a strategic response to a given historical urgency. ${ }^{4}$ In contemporary China, the life spectacles described below serve as governmental apparatuses because they respond to a pressing need for a middle class 'harmonious' society. In an event like the festival on July 15 2000, each interpretation claims to designate life as an empirical correlation between body (or the materiality that life requires) and language, as if the politics of life is only the politics of the body's

\footnotetext{
${ }^{3}$ It is characterized by new forms of organization and new flexible regimes of accumulation, such as transnational labor organization, just-in-time production, and financial market de-regulation: see, for example, David Harvey (1989), Scott Lash (2003), John Urry (1995), Manuel Castells (2000), Luc Boltanski (2008), and Paolo Virno (2004).

${ }^{4}$ By strategy, Michel Foucault means a positive manipulation of power in a mutually supporting relationship to certain types of knowledge. A strategic government response (to an urgent incident) may be formulated in a number of ways: developing power relations in a particular direction, or blocking them, stabilizing them, and utilizing them (1980: 194-196). With respect to 'apparatuses,' Giorgio Agamben defines them as 'a set of practices, bodies of knowledge, measures, and institutions that aim to manage, govern, and orient - in a way that purports to be useful — the behaviours, gestures, and thoughts of human beings' (2009: 12). And the central issue in studying apparatuses in the contemporary world is the formation of subjects, or subjectification, in the 'relentless fight' between 'living beings' (or substances) and 'apparatuses' (2009: 14).
} 
relationship to language or communication. ${ }^{5}$

\section{'Folk television:' Private production of life spectacles}

The development of the Beijing Television Station Life Channel (BTVLC) as a private television production company represents a significant step in the reform of the television industry. Under the socialist planned system, Beijing Television Station (BTV), one of the largest television stations in China, used to combine both production and broadcasting. Beginning in Spring 2000, however, it tried to experiment to separate production from broadcasting. Its collaboration with Beijing Yinhan Cultural Communications Ltd (Yinhan) led to the launch of the newly formed BTVLC. Technically, BTV owns BTVLC, and, in principle, also controls the station's media content and broadcasting. In practice, however, it allows Yinhan to independently produce and broadcast BTVLC content. BTVLC exemplifies the phenomenon that Chinese television professionals call 'the separation of production from broadcasting,' one of the most important reforms in the television industry that began after the then Chinese leader Deng Xiaoping's trip to the south in 1992, and that intensified on the eve of China's entry into the World Trade Organization (WTO) in 2001.

In this section, I discuss how this important reform gave birth to what Chinese scholars call 'folk television' (minjian dianshi). I argue that the rise of privately produced television programs serves the function of governing Chinese citizens in a new way. Specifically, media companies deploy the spectacle as an effective technology for describing and defining what everyday life is and should be. This mode of communication involves three elements: the separation of social issues from (official) politics in news production; the independent producer system; and the financing of production through advertising revenues.

\footnotetext{
${ }^{5}$ In Logics of Worlds (2009), Alain Badiou is critical of the generalized politics of speaking 'life' and its derivatives, such as 'forms of life,' 'constituent life,' and 'artistic life.' Under the communicative regime of things, Badiou writes, "life" designates every empirical correlation between body and language. And the norm of life is ... that the genealogy of languages be adequate to the power of bodies' (2009: 35). His work offers a radical response to various contemporary governmental regulations of 'life' through democratic languages and communications. Badiou challenges us to rethink of life as subjective, that is, faithful to what is uncounted and unaccountable by any regimes of living: 'Life is a subjective category. A body is the materiality that life requires, but the becoming of the present depends on the disposition of this body in a subjective formalism, whether it be produced ... erased ... or occulted ... To live is thus an incorporation into the present under the faithful form of a subject' (2009: 508). Effectively, Badiou suggests that it is impossible to live outside any normative regime of life, which formulates its life world according to certain governmental logics; thus, to live in a way that cannot be counted and accounted by a regime of living means to make a decision about what is uncountable and unaccountable.
} 
From China Central Television's famous news programs on social issues to BTVLC's programs on life, documentary has become the preferred genre for representing how ordinary Chinese people live. This development began in spring 1992 when a group of journalists from China Central Television (CCTV) followed Deng Xiaoping to the Shenzhen Special Economic Zone in Guangdong Province. Deng's trip became a turning point for the government, which now affirmed economic development as the nation's dominant policy. The CCTV journalists' trip, which led to the production of 'The Trip to Guangdong' (Guangdong xing), a documentary about the achievements of economic reforms in Guangdong, similarly became a milestone in television journalism. The show's producers carried out a heated debate over the appropriate style of journalism for describing what had been occurred in Guangdong. Eventually, they decided on 'documentary' (jishi) as a more appropriate mode of journalism than the conventional propaganda mode (Sun n.d.). Since the 1993 broadcast of the show, documentary has gradually become the standard for television journalism and, in recently years, has expanded into avant-garde video and commercial film productions, such as the works of Wu Wenguang and Jia Zhangke.

The institutional standardization of the documentary mode of television journalism began with CCTV's establishment of the 'News Commentary Department' (xinwen pinglun $\mathrm{bu}$ ), which launched two news programs that immediately became popular across the country. 'Eastern Time and Space' (dongfang shikong), a 60-minute news program first broadcast on May 1, 1993, was the country's first morning news program. It has been credited as 'the Shenzhen of the television industry' (dianshijie de Shenzhen) to highlight its pioneering role in reforming China's television industry. ${ }^{6}$ 'Focal Investigation' or 'Focus Interview' (jiaodian fangtan), a 15-minute evening news magazine first broadcast on April 1, 1994, draws the successful experience of 'Eastern Time and Space' but focuses on in-depth reporting on serious social issues. Both programs have moved away from conventional television journalism that added heavyhanded voiceovers to recorded images. Instead, to 'capture the natural flow of life' and to 'reflect the true state of life' (Luo \& Lu, cited in Zhao 1998: 115), these programs rely on such techniques as on-the-spot reporting, street interviews, synchronous sound recording, naturalistic lighting and camera angles. In this way, they have established a

\footnotetext{
${ }^{6}$ My discussion of 'Eastern Time and Space' and 'Focal Investigation' here draws on Sun Yusheng's memoir (n.d.).
} 
standard professional practice of television journalism in reporting 'life' (shenghuo). ${ }^{7}$

'Eastern Time and Space,' for example, includes five eight-to-nine-minute segments:

'Sons of the East' (dongfang zhizi), profiles of distinctive individuals; 'Top Music List of Eastern Time and Space' (dongfang shikong jinqubang), MTV style videos, background information, and interviews with singers and musicians (stopped in 1996); 'Life Space' (shenghuo kongjian), ordinary people and daily lives; 'Focal Moment' (jiaodian shike), an in-depth look at a single issue related to current affairs; and, 'Call a Spade a Spade' (shihua shishuo) (added in 1996), talk-show style discussion of different opinions on social and moral issues. These program segments are devoted to social and economic issues, and to various aspects of everyday lives that are outside the official domain of politics. Notably, 'Life Space' follows the motto of 'telling ordinary folks' own stories' (jiangshu laobaixing ziji de gushi) (Chen 2001). In contrast to the conventional approach of using models - a characteristic of the Communist Party's propaganda style of journalism — to represent voices of 'the people' (renmin) or 'the masses' (qunzhong), as Yuezhi Zhao points out, the program's portrayal of 'the ordinary and the trivial' (fanren shoushi) 'publicizes the pleasures of ordinary people, celebrates their values, their dignity, their feelings, and the beauty in their personalities and their lifestyles' (1998: 119).

The evening news magazine 'Focal Investigation' covers 'hot' issues and figures, domestic social events and problems, international events and problems, major policy issues and their background analysis, as well as new phenomena and problems emerging during the era of economic reforms. What differentiates it from other news programs like the popular 'Evening News' (xinwen lianbo), which was launched in 1978 , is its in-depth nature. Rather than presenting formal scholarly discourses or official opinions, it offers 'facts.' As it becomes more and more influential and popular,

\footnotetext{
${ }^{7}$ One may compare this television genre with 'reportage literature' (baogao wenxue), which Charles Laughlin defines as 'any deliberately literary non-fiction text that narrates or describes a current event, person or social phenomenon' (2002:2). Reportage literature originated in the works of the League of Left-Wing Writers in the 1930s but became a literary canon in the 1980s. One important issue raised by the genre is the link between narrative and media forms. Liu Kang and Xiaobing Tang place reportage between two narrative forms: the collective master narrative; and personal testimonies, memoirs, and fantasies. As a narrative form, reportage is informed by the implacable tension between official ideology and the experience of everyday life (1993: 8-20). Liu Kang and Xiaobing Tang's argument can be extended to a discussion of the relation of media to the portrayal of everyday life. Although reportage is concerned with the experience of everyday life, it is limited by its literary form. By contrast, the television medium in representing 'life' highlights the problem of the spectacle in visual communication. In this context, the canonization of 'life' television extends reportage by using diverse forms of media.
} 
it often leads to official government responses. By 2002, the State Council even established an official mechanism to address major problems showcased by the program.

Besides its focuses on social issues and daily lives, the News Commentary Department also establishes an independent news production system. According to Sun Yusheng, the Department Head and the chief architect of both 'Eastern Time and Space' and 'Focal Investigation,' 'Eastern Time and Space' was CCTV's first news program that adopted the contract system to produce and finance news production and broadcasting. The program acquired fifteen regular staff from CCTV and hired about one hundred additional staff by contract, including Chen Meng, the producer of 'Life Space,' and Cui Yongyuan, the host of 'Call a Spade a Spade.' Due to the program's successful staff organization, CCTV eventually applied the contract system to its entire work force in 2000. Every employee at CCTV, whether new or old, is required to sign a contract. In addition, CCTV formalizes a new policy about recruiting talent through open merit competitions. By 2002, for example, at least 690 staff members had been hired through this system.

'Eastern Time and Space' and 'Focal Investigation' also pioneer the use of advertisement revenues to finance production. In the beginning, the former was permitted to allocate five minutes and the latter two minutes for advertising purposes. Both programs became extremely successful in generating advertising sales. Not only did they use advertising to support program production, but they also generated additional incomes for CCTV. The advertising rate of 'Eastern Time and Space' in the first two weeks of the show, for example, was 2,500 Yuan per 30-second. In the next two months, the advertising rate was increased to 3,500 Yuan per 30-second. By the end of the first year, the rate skyrocketed to 25,000 Yuan per 30-second. In the second year, the program began to generate profits for CCTV. In its first ten years of operation, the program's profits accumulated more than one billion Yuan.

The successful and highly regarded CCTV's News Commentary Department trains talented producers to eventually become influential figures in reforming the country's television industry. Wang Jianping, for example, first became the producer of 'Top Music List of Eastern Time and Space,' a program that made music television popular in China. Several years later, Wang joined 'News Investigation' (xinwen diaocha), a news program established in 1995. There, Wang became a colleague of Xia Jun, who 
directed the famous six-episode television documentary series 'Deathsong of the River' (Heshang), one of the most popular TV programs among Chinese intellectuals and college students in the 1980s, and an important cultural product that played a critical role in promoting market-oriented social and cultural reforms in the second half of the 1980s (Bodman and Wan 1991).

In spring 2000, both Xia and Wang left CCTV to establish a new independent television production company, Beijing Yinhan Cultural Communications Ltd. Xia became Yinhan's Chief Executive Officer and Wang its General Manager. Under Xia and Wang, Yinhan furthered the development of 'life' as an important television genre. The company took 'life' as the leitmotif of its operations by following the motto of 'originating in the ordinary folks (zhigen baixing), gluing to life (tiejin shenghuo), serving life (fuwu shenghuo), and creating life (chuangzhao shenghuo)' (Beijing Youth Weekly, 3 July 2000, 14). Under Yinhan's management, the old life channel of Beijing Television Station became restructured as a new company under the name of BTVLC. A new line of five regular weekly programs was launched: 'Life in a Whole Day' (shenghuo quan tian hou) (7:00 A.M., 12:00, 7:30 P.M., daily); 'Glamour 2000' (meili 2000) (9:00 P.M., Monday-Friday); 'Nightline E-mail' (yexian E-mail) (11:00 P.M., daily); 'Beijing Model' (Beijing bangyang) (8:30 P.M., Saturday); and 'Face to Face' (yuanjia peng peng tou) (8:30 P.M., Sunday). These programs covered a wide range of topics about everyday life, including news, entertainment, technology, shopping, and lifestyle.

The establishment of Yinhan and its affiliate BTVLC, therefore, was a significant event in the history of China's television reforms. Since the founding of the first television station (Beijing Television Station, later renamed as China Central Television) in 1958, the government had managed all television stations according to the four levels of administration: county, city, province, and nation. At the same time, the government owned and strictly controlled all stations and their programs. Each station had to both produce and broadcast its programs (Zhang 1997). Neoliberal reforms, however, gradually affected cultural institutions. In 1998, the government began to reform stateowned enterprises, particularly those in the manufacturing and service industries. Drawing on the successful experience of its News Commentary Department, CCTV had an internal discussion about its planned separation of production from broadcasting. 
Meanwhile, new private television companies began to appear. Wang Changtian, a former producer at Beijing Television Station, established Beijing Guangxian Television Planning and Research Center-later renamed as Enlight Media (guanxian chuanmei) — and launched 'China's Entertainment Reports' (Zhongguo yule baodao) in 1999, a successful entertainment program that was first sold to and broadcast by the Hunan Television Station in the same year (for details, see Zhao 2008: 219-226).

Like Enlight Media, Yinhan was one of the earliest cases of privatization in China's television industry. Prior to the nationwide standardization that separated production from broadcasting in the television industry in 2003, two years after China's entrance into the WTO, Yinhan's operation of BTVLC led to the development of 'folk television' (minjian dianshi). Regarding BTVLC's separation of production from broadcasting, Yinhan invested 80 million Yuan to own 80 percent of BTVLC. Yinhan controlled BTVLC's management and operations while Beijing Television Station maintained its ownership. Nevertheless, Yinhan's managerial control of BTVLC represented a partial privatization of Beijing Television Station. As discussed earlier, CCTV's News Commentary Department successfully deployed the market mechanism (that is, advertising sales) to finance its production, but it did so within CCTV and without privatizing any broadcasting channel. By comparison, Yinhan further pushed the reforms. Yinhan used the market mechanism to finance its production; but it also practically controlled BTVLC and operated it as a private company.

Both the separation of production from broadcasting and the rise of 'folk television' contribute to the government's objective of enlarging the service sector of the economy. In a speech at the 'First Forum of China's Film and Television Industrial Capital,' Long Yongtu, China's chief WTO negotiator, made clear that the Chinese government considered the film and television industries part of the service sector of the economy, along with banking, insurance, the stock exchange, telecommunication, transportation, tourism, accounting, legal services, and consulting. In 2000, this sector counted for only 35 percent of China's GDP, whereas in the USA, the service sector accounted for 70 to 80 percent of GDP (Long 2000). China's entrance into the WTO was viewed as a further step toward the enlargement of the service sector. In fact, China's objective, as Long points out, was to gradually increase the percentage of the service economy to match the level of a developed country, a necessary step toward becoming a 'middle- 
level developed country' by the mid twenty-first century (Long 2000).

The reforms carried out by CCTV and Yinhan contributed to this long-term objective of national development. The reforms show the complicated relationship between the development of documentary as the dominant mode of visual communication in television journalism, the creation of 'life' as a popular television genre, and the privatization of program production. The portrayal of everyday life in the documentary mode sets up a standard for inspecting Chinese lives through quotidian details. Life emerges as a rich visual poetry, or a concrete and transparent sequence of activities with seemingly unsolvable ambiguities and tensions. This aestheticization of everyday life is underpinned by market realism, the operation of the market logic through selling advertisements and privatizing program production, and even broadcasting.

A further understanding of these connected issues, then, requires us to situate the television industry within the burgeoning cultural industries in the service sector of the Chinese economy. Contemporary cultural industries do not operate in isolation; they work closely with program production and distribution, as well as with sales. Moreover, they operate the spectacle as the means of production for communicating both what everyday life is, or should be, and how everyday life should be conducted properly. The following discussion of the event on July 15, 2000 addresses these issues by focusing on an important link between the two forms of cultural production represented by BTVLC and the Chinese Ethnic Culture Park. The two different interpretations of the ethnic festival operate, I argue, as life spectacles through a productive synergy that connects media communication and affective work.

\section{Business synergy, media convergence, and affective work}

Synergy is an important issue in understanding contemporary cultural industries. In the info-tech and entertainment industries since the 1980s, synergy has been developed as a key business technique in many parts of the world to integrate knowledge, information, and technology in generating profits. ${ }^{8}$ That is, synergy generates the 'added value' resulting not from the cumulative effect of the elements (knowledge, information, and technology) but from their interaction (Castells 2000: 419, 421). In Hollywood, synergy is treated as 'the governing economic logic' (Maltby 1998: 40) for creating complex

\footnotetext{
${ }^{8}$ This new mode of capital accumulation is referred to by Scott Lash and John Urry as 'reflexive accumulation' (1994: 60-61).
} 
connections between different types of media, practices and products, and/or narratives. Synergy often involves the production and distribution of a chain of interrelated products: books, television shows, records, toys, games, videos, T-shirts, magazines, as well as tie-ins and merchandizing arrangements with the entire panoply of consumer goods. ${ }^{9}$ In the theme park industry, the built environment itself is often used as an interface between entertainment, advertising, marketing campaigns, and public relations activities. Disney's theme parks provide an excellent model for media companies to learn about making connections across such different industries as banking, transportation, energy, telecommunications, fast food, soft drink, and computing goods. Disney always uses a built environment to integrate sales of licensed images and merchandise, promote new lines of products, and coordinate tourist activities with other events, like film releases (Davis 1996: 399-422) and sponsor advertising. ${ }^{10}$

At the Chinese Ethnic Culture Park, synergy generally facilitates interactions among displays of ethnic minorities, festival activities, special events, news media, and the built environment. ${ }^{11}$ In the evening of July 15,2000 , when three BTVLC journalists (one reporter and two cameramen) came to the park to shoot a three-minute news story, they affected the ethnic festival in many ways. Its regular schedule was modified to accommodate the news crews. The theme park company actively promoted the park's daytime and evening tourist programs. The ethnic minority performers diligently represented their local governments in an effort to promote ethnic tourism in their regions. To be more effective in front of the camera, they wore their most elaborate festival clothing and performed with an elevated degree of enthusiasm. During the media event, the built environment became an interface between marketing, advertising, sales, television production, and affective work.

\footnotetext{
${ }^{9}$ For a detailed discussion of the film Jurassic Park (1993), see Balides (2000). Another good example is the Disney film Hercules (1997); see Wasko (2001: 69-83).

${ }^{10}$ Exhibits at the ECOPT Center, for example, are sponsored by such companies as General Electric, General Motors, Exxon, Kodak, and Kraft Foods (Fjellman 1992). Corporate sponsors at Disneyland Paris include Renault, Banque Nationale de Paris, Europcar, Kodak, Nestlé, Coca-Cola, Philips, Esso, France Telecom, American Express, IBM, and Mattel (Lainsburg 2000: 90-93).

${ }^{11}$ The development of theme built environments in China is part of a global trend in similar hybrid forms of consumption - shopping is intertwined with entertainment (through cinema, games, and amusement rides), education (through stories and themes), merchandising (through copyrighted images and logos), performative labor (of the front-stage employees), and control and surveillance (of both employees and consumers) (Bryman 2004). The use of storytelling as a technology for building and operating an environment for the sake of consumption is common among theme parks, shopping malls, festival markets, theme restaurants, and gated communities. For this reason, my use of 'built environment' is intended to group these diverse activities together.
} 
Outside the main entrance, the park's ceremony of singing and dancing to greet visitors normally started at 19:00 and ended at 19:20. However, because the news crew came late and a cameraman wanted to repeat the shooting three times, the welcoming ceremony was extended to 19:40. Before the arrival of the news crew, about twenty residents, who lived nearby, gathered to watch the welcoming performance. Five female and five male Jingpo workers were lining up in two rows: female dancers weaving redcolour fans on one side and male performers playing music instruments on the other. By the time the news crew arrived, as many as forty people, including local residents and migrant workers, had gathered.

The media event became an excellent opportunity to promote the theme park's programs - from the nightly festival, 'Chinese Ethnic Night' to its daytime activities. A senior manager worked diligently to coordinate the event. All programs were to be shown on time, and all lights turned on to illuminate night scenes. She arranged for reporters to witness and experience as many activities as possible. For example, the 'ethnic' food flavors, boiled spiced peanuts, fresh soybeans, cold noodles, and cold drinks available at the restaurant underneath the Taiwan Aborigines' Village were also served at the Dai Village, the festival site. The food department reserved a table of food for the news crew. During the festival performance, the hostess announced daytime and evening programs several times, and emphasized the park as 'the best place for cooling off and spending leisure time during the hot summer.' These carefully coordinated efforts transformed the visit of the TV crew into a public relations campaign, which the manager referred to as a form of 'soft advertising,' that is, commercial promotion with little or no monetary cost, and an indirect in-show address to the consumer. ${ }^{12}$

While the theme park company treated the news coverage as a form of advertising, the two local governments that participated in the park's operations - the Dehong Prefecture of the Dai and the Jingpo, Yunnan Province, and Guinan County of the

\footnotetext{
${ }^{12}$ I was told that the financial need of the park was urgent because of the mounting costs of constructing the park's South Site, which began in November 1997. By Summer 2000, the cost for the South Site had reached to more than 1 billion Yuan (about US $\$ 120$ million based on the 2000 exchange rate of US\$1= 8.3 RBM). The total cost was expected to reach 2 billion Yuan. The huge construction cost affected the operation of the North Site. Although the North Site began to make profits after 1999, it had to reduce its direct operational costs, including its advertising budget. Under financial pressure, the park had to make 'soft advertising' effective through media events such as the opening and closing parties of the $20^{\text {th }}$ Convention of the International Association of Architects and the $50^{\text {th }}$ birthday celebration of the People's Reupblic of China. The company estimated in 1999 that soft advertising had saved at least 30 million Yuan (about US\$3.61 million) in advertising fees.
} 
Hainan Prefecture of the Zang, Qinghai Province_-also took advantage of the opportunity to promote local tourism. They trained and sent ethnic minority performers to work at the park. They also provided necessary equipment and uniforms to the performers. The ethnic workers became effective spokespersons for local tourism. That evening, the Dai, Jingpo, and De'Ang performers purposely promoted Dehong's local cultures through singing, dancing, and costume displaying. They repeatedly mentioned the name of Dehong during interviews. The festival's hostess invited tourists to visit Dehong, a place full of 'enchanted mountains, delightful rivers, and even more importantly, beautiful people. ${ }^{, 13}$ During my observations and interviews at the park during fieldwork trips from 1996 to 2007, I was told that an event like this was a great opportunity for the local governments. For example, Dehong, which did not appear on any nation-wide news media, was mentioned for the first time in 1999 by CCTV 's 'Evening News' in a report about the park's activities.

For ethnic performers, the media event became an intense situation in which they had to accommodate the news media, satisfy their employers, and of course, make visitors happy. Usually, an ethnic performer's main responsibility is to stage performances several times a day. Her work is characterized by a paradox of repetition. On the one hand, repetition gives a familiarity to work. This means that the performer need not often learn and practice new song lyrics and dance moves. Repetition also becomes mechanical and boring for the performer, and thus eventually for her audience. It makes it difficult for her to provide the exciting experience expected by visitors, especially those who consider the entrance fees very expensive. ${ }^{14}$ As my own observations and interviews confirmed, ethnic performers were clearly aware that tourists treated their performances and dressed bodies as spectacles and objects for photo opportunities. Nevertheless, ethnic workers considered such tourist behaviour to be routine. In this situation, some of them became reflexive, consciously managing their own feelings as a

\footnotetext{
${ }^{13}$ She said: 'The Dai people, who are hardworking, brave, and good at singing and dancing, live at this magical and beautiful land. Wherever you come from - whether from the north, the south, the snowmountain, or from the grassland; and whoever you are - a stranger from afar or a friend who hasn't been seen, once you arrive at a Jingpo mountain village, the Jingpo will offer you a cup of pure, clean, and light wine. You will experience nature, far away from the city ... We will forever open the gate of our village and warmly welcome you, our guests.'

${ }^{14}$ The management of a tourist activity has to take into account the subjective experience of a tourist, because the relationship between the objects and services purchased and a good leisure experience is not merely objective but also reflexive. As John Urry points out, 'many of these services involve the production and consumption of a particular social experience which cannot be reduced to, say, the details of a restaurant menu' (1995: 131, original emphasis).
} 
way to address the gap between their own mechanical work experience, and visitors' expectation of receiving an exciting experience. ${ }^{15}$

A media event like the visit of the BTVLC news crew seems to elevate the quotidian to the status of the extraordinary. It creates an exceptional situation in which ethnic workers must outperform themselves, rather than providing just another routine performance to satisfy visitors' expectation. They must also perform to capture the potential television audience, not to mention represent positively their own ethnic groups and their employers. That evening, ethnic performers excelled. The Jingpo performers wore their best festive dresses. Rather than their daily velvet skirts, they put on their traditional red-color linen skirts. Their jackets were decorated with shining silver-color metal bells. The Dai female performers wore long metal fingernails in a 'royal dance.' The three leaders, who were appointed by local governments to manage the daily lives of the ethnic minority performers, also changed their everyday attiresusually indistinct from that of visitors - to ethnic uniforms. The Zang leader went on the stage to show off his skills in singing and dancing. Charming smiles, elegant clothing, and an energetic performance even impressed the park's manager, who mentioned to me that the ethnic performers 'were excited at the presence of news media.' Managerial recognition of their work's exceptional quality was a clue to how important affective work was to the success of a synergistic event.

For the BTVLC news crew, their intention was to report the festival as a summer leisure activity of Beijing residents. They presumed the festival to be informal, fun, and entertaining. The reporters all wore causal clothing appropriate to the context. For example, the female reporter (in her early twenties) dressed in a leisure look typical of a young Beijing woman. She wore a white short-sleeved shirt with thin, blue strips, white capri pants, and white low-heel sandals. At the entrance, as a cameraman was setting up the camera and adjusting lighting, she unbuttoned her shirt, appearing more relaxed and more like an ordinary tourist. Then she put on her smile, and spoke with a soft, clear,

\footnotetext{
${ }^{15}$ In comparison, Disney has developed a method for managing this gap. For Disney performers (or 'cast members' in Disney's corporate vocabulary), their work is repetitive, but it is also literally a performance. 'Cast members' dress up to enact fantasy characters like Snow White, Goofy, and Mickey, all from Disney animation films. During a performance, an employee brings a film character back to life. The animated character conceals the feelings of the performer. The smiley face of Mickey Mouse is the only expression required. From the visitor's viewpoint, Mickey's smile does not come from the animation of his performer; rather the smile comes from the mask itself. Thus, Disney's 'magic' for successfully delivering customer satisfaction and expectations relies on the concealment of work from the scene of performance (The Project on Disney 1995).
} 
and enthusiastic tone. 'Viewers, we are arriving at the Chinese Ethnic Culture Park to witness the welcoming ceremony of the Jingpo people from the Dehong Prefecture of the Dai and the Jingpo, Yunnan Province. According to a park staff member, the Jingpo perform this ceremony every evening. Let's ask how the Jingpo say "greetings."' In her interview with Jingpo performers, she focused on ordinary 'facts.' She asked performers to say 'greetings' in Jingpo and to explain the meanings of Jingpo song lyrics in Chinese. She also asked whether they made their own clothes and how men and women dressed differently.

Although the news report did not include journalists' comments on the park's representations of ethnic cultures, they did have opinions. They told me that they thought that the festival's content was about 'politics' (zhengzhi), rather than leisure and entertainment. In fact, it was clear to every viewer that the park's ethnic performances combined both patriotic education and multicultural representation. The festival began with a group dance by several ethnic minority groups (Jingpo, Zang, Dai, Miao, Yi, and De'Ang). As soon as the dance began, the pre-recorded song, 'Loving Our Chinese Nation' (Ai wo zhonghua), was played. Meanwhile, the hostess spoke to the audience through a microphone:

\footnotetext{
We are a multiethnic nation. The brothers and sisters of the fifty-six ethnic groups [minzu], who live under the same blue sky, are related to each other and love each other. Connected through our hearts, we build and administrate our homeland. At Beijing's Chinese Ethnic Culture Park, you can look at every ethnic group's architecture, enjoy every ethnic group's clothing and decorations, and taste every ethnic group's delicious foods. This place is the encyclopaedia for understanding all ethnic groups in China; it is the garden for experiencing the charisma of the Chinese people.
}

The announcer continued to introduce the clothing of several ethnic minority groups, including the Jingpo, Miao, Yi, Uygur, Korean, and Zang. In the end, she told the visitors: 'Let us understand ourselves better; and let the world understand us better.' This final message, for ordinary visitors and the journalists, was simply meant as an extension of the theme of promoting multicultural education. However, for the ethnic theme park, it has become of the company's most often used statements in its advertising and public relations materials. It is printed on the park's brochures, fliers, and tickets, and posted on two giant billboards outside the park. The inclusion of the statement during the media event was an instance of soft advertising, with the aim of promoting the park's key business operation of integrating multicultural education into tourism. 
The informal character of multicultural education at the theme park apparently did not impress the visiting journalists. For them, there ought to be a clear distinction between 'politics' and ordinary 'life' (shenghuo). One reporter explained to me what 'life' meant. 'Life' was 'non-political'; it referred to 'what the "ordinary folks" (laobaixing) do, that is, eat (chi), drink (he), shit (la), pee (sha), and sleep (shui), everything except for "politics" (zhengzhi) in "everyday life" (richang shenghuo).' The reporters felt that the ethnic theme park appeared to be a 'governmental institution' (zhengfu jigou), rather than a private company. The festival, in which the park staged its representation of ethnic minorities as a form of entertainment, did not match the reporters' expectation of it as an example of ordinary 'life.'

The different understandings of ethnic performance, as a 'political' activity (for BTVLC) and as an informal multicultural education through tourism (for the ethnic park), reflect the different roles played by the two companies in constructing meanings of everyday life through cultural production and consumption. BTVLC's treatment of 'life' as merely mundane and ordinary in the historical context of reforms in the television industry (see the previous section) cultivates meanings of everyday life that were not adequately addressed by state-owned and -controlled television stations. By comparison, the ethnic park approaches everyday life as a combination of leisure and work, or of entertainment and education. In this way, the park explicitly addresses the relationship between cosmopolitan citizenship and life conduct, an increasingly important issue in the context of China's participation in globalization. Thus, despite their differences, both companies' representations of ethnic performance in relation to everyday life share the same objective of shaping everyday life through cultural production and consumption. In that context, the event on July 15, 2000, created an opportunity for the two companies to join forces in a particular way. This was done through synergy, a productive technology for knowledge generation, information processing, and symbolic transmission (Castells 2000: 21, note 31). Not only did synergy operate through media convergence (that is, between television and the built environment); it also demanded an exceptional performance of affective labour by the ethnic minority workers involved.

\section{Conclusion: Managing social risks through life spectacles}

From 'folk television' to cultural theme parks, modes of the spectacle are developed in 
correspondence with the changing meanings of everyday life. For the television industry, as exemplified by CCTV and BTVLC, reforms in program production and broadcasting have hinged on changes in the way in which the meanings of 'life' are communicated through spectacles. One particular mode of communication, which has emerged as a national standard for television production, is the documentary form of representation, or factual descriptions of the mundane activities of ordinary people and social issues that have emerged in the unofficial terrain of everyday life. This new mode of visual communication is inseparable from a neoliberal process in television production, the privatization of production and distribution (including broadcasting). ${ }^{16}$

Similarly, for the theme park industry, the spatial techniques used in the operations of a theme built environment are closely related to the development of leisure and consumption as two important cultural problems of everyday life (Ren 2007). To address leisure and consumption problems in the Chinese Ethnic Culture Park, the company deploys the theme built environment as a means to shape the movements of consumers. What visitors consume includes not only cultural representation of ethnic minorities on the basis of specialized knowledge (like ethnology and folklore), but also the information acquired through their embodied experiences of walking through an ethnic village, watching an ethnic performance, and tasting ethnic food. Thus, this mode of the spectacle is characterized by spatial consumption. It relies on the private control of the built environment by the theme park company and on each visitor's interactions with the objects on display and the environment. This explains the park general manager's statement that cultural tourism 'links together knowledge, entertainment, participation, and taste' and thus serves the purpose of 'both guiding tourists to look and directing them to play. ${ }^{, 17}$

The above two modes of life spectacles, life as mundane and unofficial and life as an individual conduct of consumption or/and leisure, work together in an event of media convergence. In the case of the event on July 15, 2000 the convergent relationship

\footnotetext{
${ }^{16}$ Recently, reality television promotes interactions between a show and its viewers. In such popular shows as 'Super Girl' and 'Super Boy' (both produced by Hunan Satellite Television), viewers may interact with these programs by casting votes through their cell phones or the Internet. This kind of interactive entertainment always nudges spectators to act out or exercise their consumer power for the purpose of making a show profitable. In a country like China where political democracy is underdeveloped (if not completely lacking), the popularity of the commercial form of participation is very striking and ironic.

${ }^{17}$ Wang Ping, General Manager of Beijing's Chinese Ethnic Culture Park.
} 
between television and theme built environment was established by business synergy. The contents of the ethnic festival notwithstanding, many boundaries of everyday terrains of life - the mundane, leisure, consumption, and work — became blurred and were even transcended. A particular force that made synergy effective in this media event was the affective labour of ethnic minority workers. If synergy is considered as an outstanding technology of accumulation for cultural industries, its power hinges on the exceptional force of affective labour - in this case, that of the ethnic minority workers.

So why is it important to examine the development of different modes of life spectacles in contemporary China? To answer this question, it is necessary to consider the development of social risks and ways of managing them in a country that has rapidly become not only 'one of the world's fastest-growing economies' but also 'one of the most unequal societies. ${ }^{18}$ The problem of risks in this paradoxical context, for example, the polarization of wealth and poverty, results from the implementation of the Chinese government's neoliberal policies. In socialist China, the people as a whole were discursively constituted as the master of the socialist state and were treated according to the principle of egalitarian equality. In reform-era China, this principle of equality has been abandoned. Reforms have opened up opportunities for some people while sealing off opportunities for others. The development of culture industries also reflects and further contributes to China's neoliberal process. ${ }^{19}$ As I have shown in this essay, there has been a close connection between the rise of 'folk television' and the privatization of television production and distribution, at least partially, since 1992.

Similarly, the rise of theme built environments such as theme parks, shopping malls, and residential communities across the country has resulted from the privatization of real estate development. It should be noted that this privatization both results from and extends the long and meandering process of incorporating capitalism into China's socialist system. From 1980 to 1992, experimentations with capitalism were limited to a series of economic zones such as the Shenzhen Special Economic Zone, which was

\footnotetext{
${ }^{18}$ To mention a few examples: 20 percent of the population holds 80 percent of total bank deposits; peasants make under US\$300 a year, while people in Shanghai (the richest city in China) earn over US $\$ 4,000$ a year; and the recent Gini coefficient of 0.45 suggests that economic inequality in China has in fact surpassed that of the USA and the UK with their allegedly cold-blooded 'Anglo-Saxon' model of capitalism (Sisco 2005).

${ }^{19}$ For detailed discussions of recent media changes, such as administrative reforms (according to market logics), the conglomeration of news media, the diversification of both media content and form, and the development of new media, see Donald, Keane and Hong (2002) and Lee (2003).
} 
established in 1980 and remains one of the first and most successful special economic zone. A pivotal historical event allowing the government to legitimize the existence of capitalism in socialist China was the re-incorporation of the Hong Kong territory in 1997. ${ }^{20}$ After decades of negotiations, the Chinese government eventually signed a legal agreement with the British government in 1984 to guarantee that Hong Kong would retain its character as a prosperous capitalist place.

Deng Xiaoping's visit to the special economic zones in 1992 reaffirmed economic development as the leitmotif of China's future, and the development of capitalist economic zones became the national norm. Throughout the country, real estate projects began to reorganize urban space into a series of built environments (variously called zones, districts, blocks, or communities). Each was to be structured around a concept: a high-tech park, an ethnic town, a theme park, a shopping mall, a gated community, a business centre, and the like. As each city becomes a collection of these built environments, the drama of market experimentation wrestles with the disjunctures arising between socialist and capitalist modes of social relations.

China's reforms have turned Chinese society from one of the world's most equal societies to one of its most unequal. China has become a risk society in which responsibility for employment, welfare, education, health, poverty alleviation, and environment have been redistributed from government to nongovernmental organizations and from the collective to the individual. ${ }^{21}$ The rapid rise of charitable organizations in China, for example, shows a general shift from government-funded welfare to charitable work by individuals, corporations, and non-profit organizations (Shue 1998; Chen 2004). Governmental and social policies have shifted from regarding peasants and workers as model citizens to viewing them as 'disadvantaged groups' (ruoshi qunti). Their lack of various kinds of capital (political, economical and cultural), unequally redistributed during the economic reforms (Wang 2003; Li 2003; Xiao 2003), has made them less able to take responsibility for their livelihood, health care, and education. Forming the largest segment of China's population, they are viewed as a threat to the stability of Chinese society in case of a state emergency, whether economic or political crisis or even a crisis of biosecurity as in the case of an outbreak of SARS or

\footnotetext{
${ }^{20}$ This is discussed at length in Ren (2004; forthcoming a).

${ }^{21}$ Here, risk is both real and imagined in relation to the future of the state. The concept of risk society draws on Beck (1992; 1994), Beck and Beck-Gernsheim (2002), and Lash (2003).
} 
Avian Flu. To address these problems of security, government officials, policy experts and scholars advocate for the growth of a middle class (Zhongguo shehui kexueyuan 2002; Hu 2003; Qin 2003) as necessary for balancing the contradictions between economic growth and social stability produced by the economic reforms. Although the middle class is still statistically small in size, it is anticipated to grow to become the predominant social class so that the pyramidal shape of the present social structure will be transformed into the ideal olive shape (Zhongguo shehui kexueyuan 2002).

The two modes of life spectacles discussed in this article-life as mundane and unofficial, and life as individual conduct of consumption and leisure-participate in the social engineering project of developing a robust middle class society. They underline the fact that everyday life in an unstable society is deeply problematic and is subject to change toward the direction of a harmonious and stable society.

\section{Acknowledgments}

I gratefully acknowledge the support of the Wenner-Gren Foundation. My deep appreciation to Eithne Luibheid and Ann Anagnost for their critical comments. Thanks to Stephanie Hemelryk Donald, Yi Zheng and Paul Allatson for their editorial guidance, and to the two anonymous referees for their constructive comments. 


\section{Reference List}

Agamben, G. 2009, What Is an Apparatus? and Other Essays, Stanford University Press, Stanford.

Badiou, A. 2009, Logics of Worlds: Being and Event, 2, Continuum, London.

Balides, C. 2000, 'Jurassic Post-Fordism: Tall Tales of Economics in the Theme Park,' Screen, vol. 41, no. $2,139-160$.

Beck, U. 1992, Risk Society: Towards a New Modernity, Sage, London.

Beck, U. 1994, 'The Reinvention of Politics: Towards a Theory of Reflexive Modernization', in Reflexive Modernization: Politics, Tradition and Aesthetics in the Modern Social Order, (eds) U. Beck, A. Giddens, \& S. Lash, Stanford University Press, Stanford, 1-55.

Beck, U. \& Beck-Gernsheim, E. 2002, Individualization: Institutionalized Individualism and its Social and Political Consequences, Sage, London.

Bodman, R.W. \& Wang, P.P. 1991, Deathsong of the River: A Reader's Guide to the Chinese TV Series Heshang, East Asia Program, Cornell University, Ithaca.

Boltanski, L. 2008, 'The Present Left and the Longing for Revolution,' in Under Pressure: Pictures, Subjects, and the New Spirit of Capitalism, (eds) D. Birnbaum \& I. Graw, Sternberg Press, Berlin, $52-71$

Bray, D. 2005, Social Space and Governance in Urban China: The Danwei System from Origins to Reform, Stanford University Press, Stanford.

Bryman, A. 2004, The Disneyization of Society, Sage, London.

Castells, M. 2000, The Rise of the Network Society, 2nd edition, Blackwell, Oxford.

Chen, C. 2004, 'China's Charities and Philanthropists.' Online, available: http://www.china.org.cn/english/2004/Apr/94150.htm (Accessed 11 July 2007).

Chen, M. 2001, 'The Rise of Chinese Documentary Filmmaking and Its Engagement with Ordinary People.' Talk at the Symposium on 'Memory and Media in and of Contemporary China,' Center for Chinese Studies, University of California, Berkeley, March 2-4.

Davis, S.G. 1996, 'The Theme Park: Global Industry and Cultural Form,' Media, Culture and Society, vol. $18,399-422$.

Debord, G. 1995, The Society of the Spectacle, Zone Books, New York.

Donald, S.H., Keane, M. \& Hong, Y. (eds). 2002, Media in China: Consumption, Content and Crisis, RoutledgeCurzon, London.

Fjellman, S.M. 1992, Vinyl Leaves: Walt Disney World and America, Westview, Boulder, CO.

Foucault, M. 1980, Knowledge/Power: Selected Interviews and Other Writings, 1972-1977, Pantheon Books, New York.

Harvey, D. 1989, The Condition of Postmodernity: An Enquiry into the Origins of Cultural Change, Blackwell, Cambridge.

Hercules. DVD, 1997, Walt Disney Company.

Horkheimer, M. \& Adorno, T.W. 2001, 'The Culture Industry: Enlightenment as Mass Deception,' in Media and Cultural Studies: Key Works, (eds) M.G. Durham \& D.M. Kellner, Blackwell, Malden, 71-101.

Hu, A. 2003, 'Equity and Efficiency,' in One China, Many Paths, (ed.) C. Wang, Verso, New York, 219233.

Jurassic Park. DVD, 1993, Universal Pictures.

Lainsburg, A. 2000, Once Upon an American Dream: The Story of Euro Disneyland, University Press of Kansas, Lawrence.

Laughlin, C. 2002, Chinese Reportage: The Aesthetics of Historical Experience, Duke University Press, Durham, NC, and London.

Lash, S. 2003, 'Reflexivity as Non-linearity,' Theory, Culture and Society, vol. 20, no.2, 49-57.

Lash, S. \& Urry, J. 1994, Economies of Signs and Space, Sage, London.

Lee, C. (ed.). 2003, Chinese Media, Global Contexts, RoutledgeCurzon, London.

Li, C. 2003, 'The Crisis in the Countryside,' in One China, Many Paths, (ed.) C. Wang, Verso, New York, 198-218.

Liu, K. \& Tang, X. 1993, 'Introduction,' in Politics, Ideology, and Literary Discourse in Modern China, (eds) K. Liu \& X. Tang, Duke University Press, Durham, NC, 8-20.

Long Y. 2000, 'Miandui WTO De Zhongguo Yingshi Chanye' (China's Film and Television Industries Face the WTO), Yinhan Chuanbo Yuekan, nos. 3-4 (June-July), 19-22.

Maltby, R. 1998, "'Nobody Knows Everything”: Post-Classical Historiographies and Consolidated Entertainment,' in Contemporary Hollywood Cinema, (eds) S. Neale \& M. Smith, Routledge, London, 21-44. 
Marcuse, H. 1991, One-Dimensional Man: Studies in the Ideology of Advanced Industrial Society, Beacon Press, Boston.

Project on Disney 1995, Inside the Mouse: Work and Play at Disney World. Duke University Press, Durham.

Pun, N. 2005, Made in China, Duke University Press, Durham, NC, and London.

Qin, H. 2003, 'Dividing the Big Family Assets: On Liberty and Justice,' in One China, Many Paths, (ed.) C. Wang, Verso, New York, 128-159.

Ren, H. 2004, 'The Countdown of Time and the Practice of Everyday Life,' Rhizomes: Cultural Studies in Emerging Knowledge, no. 8 (Spring). Online, available: http://www.rhizomes.net/issue8/ren.htm (Accessed 25 May 2005).

Ren, H. 2007, 'The Landscape of Power: Imagineering Consumer Behavior at China's Theme Parks,' in The Themed Space: Locating Culture, Nation, and Self, (ed.) S. A. Lukas, Lexington Books, 97112.

Ren, H. forthcoming a, Neoliberalism and Culture in China and Hong Kong: The Countdown of Time, Routledge, London.

Ren, H. forthcoming b, 'The Middle-Class as a Social Norm: Consumer Citizenship in China's Reform,' in Global Futures in East Asia, (eds) A. Anagnost, A. Arai, \& H. Ren.

Ross, A. 2006, Fast Boat to China: Corporate Flight and the Consequences of Free Trade: Lessons from Shanghai, Pantheon Books, New York.

Shue, V. 1998, 'State Power and the Philanthropic Impulse in China Today,' in Philanthropy in the World's Traditions (eds) W. F. Ilchman, S. Katz, \& E. L. Queen II, Indiana University Press, Bloomington, 332-354.

Sisco, F. 2005, 'Is China Headed for a Social “Red Alert”?,' Asia Times Online, October 20.

Sun, Y. n.d., 'The Ten Years: Telling Rarely Told Stories about the Television Program' (Shinian: jiangshu dianshi jiemu xianwei renzhi de Beijing). Online, available:

Http://www.gongshe.com/bbs/dispbbs.asp?boardid=18\&id=39931 (Accessed 21 April 2006).

Urry, J. 1995, Consuming Places, Routledge, London.

Virno P. 2004, A Grammar of the Multitude: For an Analysis of Contemporary Forms of Life, Semiotext[e], New York.

Wang J. 2005, 'Bourgeois Bohemians in China? Neo-Tribes and the Urban Imaginary,' The China Quarterly, no. 183 (September), 532-548.

Wang Y. 2003, 'From Status to Contract?,' in One China, Many Paths, (ed.) C. Wang, Verso, New York, 189-197.

Wasko, J. 2001, Understanding Disney, Polity, Cambridge, UK.

Xiao, X. 2003, 'Industrializing Education?,' in One China, Many Paths, (ed.) C. Wang, Verso, New York, 237-249.

Yan, H. 2008, New Masters, New Servants: Migration, Development, and Women Workers in China, Duke University Press, Durham, NC, and London.

Zhang, Y. 1997, Dianshi Gailun (Introduction to the Television), Zhongguo Guangbo Dianshi Chubanshe, Beijing.

Zhao, Y. 1998, Media, Market, and Democracy in China: Between the Party Line and the Bottom Line, University of Illinois Press, Urbana.

Zhao, Y. 2008, Communication in China: Political Economy, Power, and Conflict, Rowman \& Littlefield, Lanham.

Zhongguo shehui kexueyuan. 2002, Dangdai zhongguo shehui jieceng yanjiu baogao (The Report on the Social Stratification Research in Contemporary China), (Lu Xueyi, editor in chief), Shehui Kexue Wenxian Chubanshe, Beijing. 